\title{
Short Communication: The effect of ethylene glycol as plasticizer against mechanical properties of bioplastic originated from jackfruit seed starch and cocoa pod husk
}

\author{
MAULIDA LUBIS ${ }^{1, \boldsymbol{v}}$, MARA BANGUN HARAHAP ${ }^{2}$, M. HENDRA S. GINTING ${ }^{1}$, SITI MAYSARAH ${ }^{1}$, ARIF GANA ${ }^{1}$ \\ ${ }^{1}$ Department of Chemical Engineering, Faculty of Engineering, Universitas Sumatera Utara. Jl. Almamater, Padang Bulan, Medan Baru, Medan 20155, \\ North Sumatra, Indonesia. Tel.: +62-61-8212090, Fax.: +62-61-8213250, `email: maulida70@gmail.com \\ ${ }^{2}$ Department of Physics, Faculty of Mathematics and Natural Sciences, Universitas Negeri Medan. Jl. Wilem Iskandar Pasar V, Medan Estate, Medan \\ Tembung, Deli Serdang 20371, North Sumatra, Indonesia
}

Manuscript received: 23 September 2017. Revision accepted: 27 March 2018

\begin{abstract}
Lubis M, Harahap MB, Ginting MHS, Maysarah S, Gana A. 2018. Short Communication: The effect of ethylene glycol as plasticizer against mechanical properties of bioplastic originated from jackfruit seed starch and cocoa pod husk. Nusantara Bioscience 10: 76-80. The addition of elasticity of bioplastic from jackfruit seed starch reinforced with cacao pod husk was studied using ethylene glycol as plasticizer. This study aimed to investigate the effect of addition of ethylene glycol as plasticizer against mechanical properties of bioplastic from jackfruit seed starch and cacao pod husk. Bioplastic was made by casting method at temperature $88.1{ }^{\circ} \mathrm{C}$ with ratios of cacao pod husk as fillers and jackfruit seed as starch were 9:1, 8:2, 7:3, 6:4, and 5:5 (w/v). The variations of ethylene glycol were from $0.2(\mathrm{v} / \mathrm{w})$ to $0.4(\mathrm{v} / \mathrm{w})$. The result showed that ethylene glycol could increase the mechanical properties of bioplastic. The best condition of bioplastic was achieved at ratio 7:3 in addition of ethylene glycol was $0.2(\mathrm{v} / \mathrm{w})$ with tensile strength of $15.40 \mathrm{MPa}$ and elongation at break $2.39 \%$. The result of FT-IR analysis indicated that bioplastics consisted of $\mathrm{O}-\mathrm{H}$ group, $\mathrm{C}-\mathrm{H}$ group, $\mathrm{C}=\mathrm{O}$ group and $\mathrm{C}-\mathrm{O}$ group. The SEM images demonstrated the bioplastic with cacao pod husk as filler and ethylene glycol as plasticizer had the fracture surfaces with the compact structure compared to that bioplastic without fillers.
\end{abstract}

Keywords: Bioplastic, casting method, ethylene glycol, jackfruit seed, tensile strength

\section{INTRODUCTION}

Plastics are most widely used in human life. However, common plastics used in society derived from conventional plastics which need decades to degrade in nature (Reddy et al. 2013). Not only need for a long time to be degraded, but it can also produce toxin in degradation process (Gross and Karla 2002). The problem of consuming conventional plastic have provoked scientist to make alternative plastics more friend environment. The alternative way is bioplastic, which can be decomposed through the enzymatic activity of microorganisms. Decomposition of biodegradable plastics can be easily transformed naturally into environmentally friendly compounds such as carbon dioxide, methane, water, biomass, humic materials and other natural substances (Azios 2007). Such biodegradable plastics can be made from hydrocolloids (proteins or polysaccharides), lipids (fatty acids, acylglycerols, or waxes), and composites (mixtures of hydrocolloids and lipids) (Skurtys 2009).

Starch is a class of polysaccharides used as the main ingredient for making biodegradable plastic. Starch is used because it is abundant, cheap, renewable and also easy to decompose (Sahoo and Rana 2006). Starch has an inherent trait and also as a carbon source (Willet 2009). This study is used jackfruit seed as starch source because it has a high starch content. Characteristics of starch-based bioplastics are still weak compared to petroleum-based plastics because starch-based bioplastics are still rigid and low strength (Zhao et al. 2008).

To overcome deficiencies of starch-based bioplastics, the addition of plasticizers through intermolecular interactions with polymer matrix can improve the characteristics and properties of starch-based films (Sanyang et al. 2015). In addition, the addition of plasticizer can improve the strength and suppress the fragility of the film (Iriany et al. 2012). Plasticizer such as ethylene glycol is added in this processing because it is easily in casting process and volatile, so that the result of product is rigid (Tajan et al. 2008; Moghaddam et al. 2009).

Besides plasticizer, the addition of fillers can strengthen the bioplastic product (Septiosari et al. 2014). Fillers derived from cellulosic materials can increase the mechanical strength of bioplastic (Chun et al. 2014). One of the celluloses used as a bioplastic preparation material can be obtained from cacao pod husk. Cacao pod husk contain $17.27 \%$ cellulose, $19.56 \%$ hemicellulose, and $52.02 \%$ lignin (Wijaya et al. 2017)

Although a number of studies have been carried out on the use of a combination of starch and natural fillers to form biodegradable plastics, no research on using cellulose fillers from cacao pod husk in bioplastic. In this study, cacao pod husk was used as fillers and ethylene glycol as plasticizer for preparation of bioplastic based on jackfruit seed starch. The effect of ethylene glycol on a starch biocomposite was evaluated using morphological studies and measurements of mechanical and thermal properties. 


\section{MATERIALS AND METHODS}

\section{Materials}

Cacao pod husk obtained from Kampung Padang, Sei Rampah, North Sumatra, Indonesia. Jackfruit seed starch was purchased by local market in Langsa, Aceh, Indonesia. Lime water was purchased by local market. The chemicals, aquadest $\left(\mathrm{H}_{2} \mathrm{O}\right)$, ethylene glycol $\left(\mathrm{C}_{2} \mathrm{H}_{6} \mathrm{O}_{2}\right)$, sodium hydroxide $(\mathrm{NaOH})$ were supplied by Merck and used as received.

\section{Preparation of cacao pod husk}

Cacao pod husk was washed with water to remove impurities. Every $5 \mathrm{~kg}$ of cacao pod husk was cut to size \pm $2 \mathrm{~cm}^{2}$. Cacao pod husk slices were soaked in lime water $\left(\mathrm{CaCO}_{3}\right)$ for 6 hours with $1 \%$ concentration where in the lime water is a mixture of 15 grams of lime in 2 liters of clean water. Lime water was used to remove the sap from the cacao pod husk. Cacao pod husk was dried under the sun for 6 hours until dry. The dried cacao pod husk that blended in smooth conditions. The blended cacao pod husk was screened by a mesh size of 200 .

\section{Isolation of jackfruit seed starch}

A total of 100 grams of jackfruit seeds was peeled its outer shell and its epidermis which was then cleaned with clean water. Seeds were cut on size $\pm 1 \mathrm{~cm}^{2}$, then put in a blender and added with water as much as $100 \mathrm{ml}$ and blended until smooth. The material was removed from the blender and filtered using a common filter until the dregs are obtained and the filtrate liquid (starch suspension). The resulting suspension was then deposited for 24-48 hours until the starch settles perfectly. The starch sludge was filtered using filter paper to the wet starch. The dried solid starch was smoothed to a powder shape which was then screened through a mesh size of 100 mesh.

\section{Production of bioplastics}

Bioplastics were based on a solution casting and evaporation process. The varied amount of cacao pod husk (1, 2, 3, 4, $5 \mathrm{wt} \%$ of starch) was dispersed into $200 \mathrm{ml}$ of distilled water under continuous stirring at $700 \mathrm{rpm}$ in 15 min. Afterward, designated weights of 10 gr of jackfruit seed starch were mixed and stirred for the complete dissolution of starch. Ethylene glycol with a varied amount $(0,2 ; 0,25 ; 0,3 ; 0,35 ; 0,4 \mathrm{wt} \%$ of starch). Starch and ethylene glycol were mixed and heated at $88^{\circ} \mathrm{C}$ for $30 \mathrm{~min}$ with stirring until it was perfectly gelatinized. This was then added with Sodium hydroxide $(\mathrm{NaOH}) 5 \mathrm{wt} \%$ to dissolve the mixture. The water was evaporated at room temperature over night. The solution was poured into an acrylic mold. The film formed uniformly was then removed smoothly.

\section{Data analysis and characterization}

Fourier Transform Infrared Spectroscopy

Functional groups were analyzed using IR Prestige-21 Shimadzu.

\section{Tensile properties}

The tensile test was performed according to the ASTM D882-02 by Instron Universal Testing Machine. Mechanical properties included tensile strength and elongation at break.

\section{Morphological characteristic}

Scanning electron microscopy (SEM) was used to examine the surface morphology of bioplastic. The measurement of the surface morphology of bioplastic was done using SEM EVO MA 10 ZEISS.

\section{RESULTS AND DISCUSSION}

\section{Tensile strength}

The tensile strength of bioplastic was shown in Figure 1. It shows that, the addition of cacao pod husk as fillers and ethylene glycol as plasticizers could increase the values of the tensile strength, and the optimum plasticizer addition was $0.2 \mathrm{ml} /$ gram. It also shows that the optimum value of bioplastic was 15,40 Mpa. Furthermore, the tensile strength of bioplastic was improved and enhanced with the presence of reinforcement. This caused, the strong interaction between starch and fillers which improved the compactness of the bioplastic formation, so that the bioplastic resistance can be increased when the tensile strength test was performed. This was in accordance with Tong et al. (2014) who reported that the incorporation of natural fiber increased the tensile strength compared with the unreinforced plastic matrix. However, if the levels of plasticizer and filler were increased continuously, the tensile strength of bioplastic film would decrease. This was because the molecular equilibrium has been exceeded, allowing excessive plasticizers and fillers to phase out beyond the matrix phase and would decrease intermolecular forces between chains which lead to freer chain movements and intermolecular forces (Yusmarlela 2009). It can be seen that there is deviation in loading filler from 2 gram to 3 gram, This might happen because of nonhomogenous filler trigger aggregate formation (Maulida et al. 2016).

As shown in Figure 1, the tensile properties of bioplastic were improved by the addition of ethylene glycol. Tensile strength of bioplastic decreases with the addition of cacao pod husk and ethylene glycol as plasticizers. The addition of plasticizers can reduce the strong intra-molecular attractiveness between the starch chains and affected the formation of hydrogen bonds between the softener and the starch molecule (Sanyang et al. 2015). Additionally, the increased number of plasticizer supplementation can decrease the mechanical properties, but it increased the percentage of elongation and brittleness as well as provided a rigid effect because of volatility and migration. In addition, there is a decrease in intermolecular forces between chains of macromolecules due to the interaction of ethylene glycol binding on the very weak macromolecule chains, resulting in the increase of free volume and causing a decrease in mechanical strength (Rahmatunnisa 2015). 


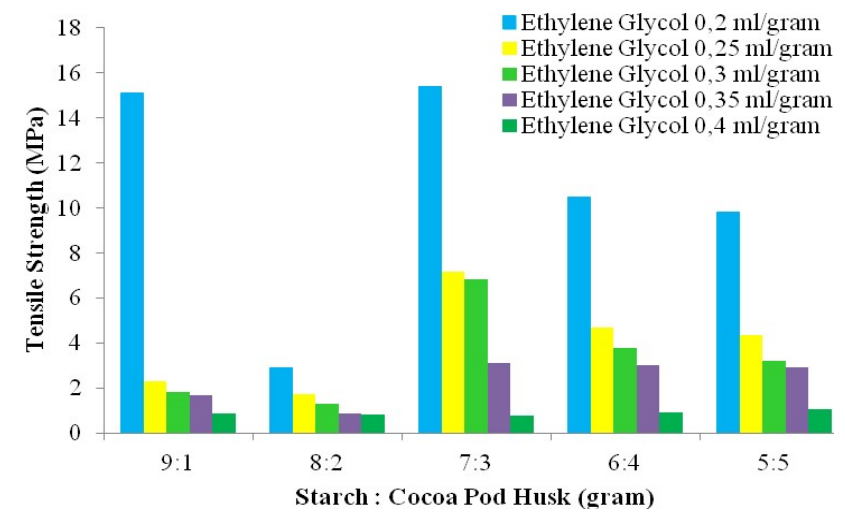

Figure 1. The effect of the addition of ethylene glycol on tensile strength of bioplastic

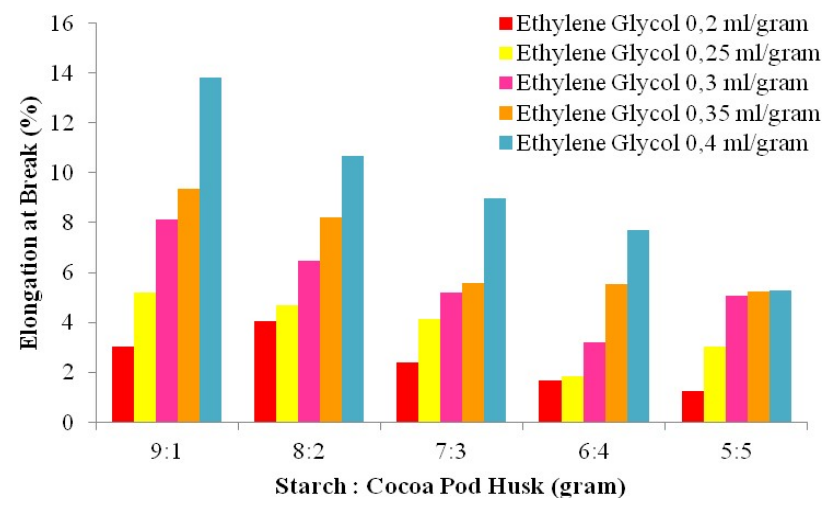

Figure 3. The effect of ethylene glycol addition on elongation at break of bioplastic

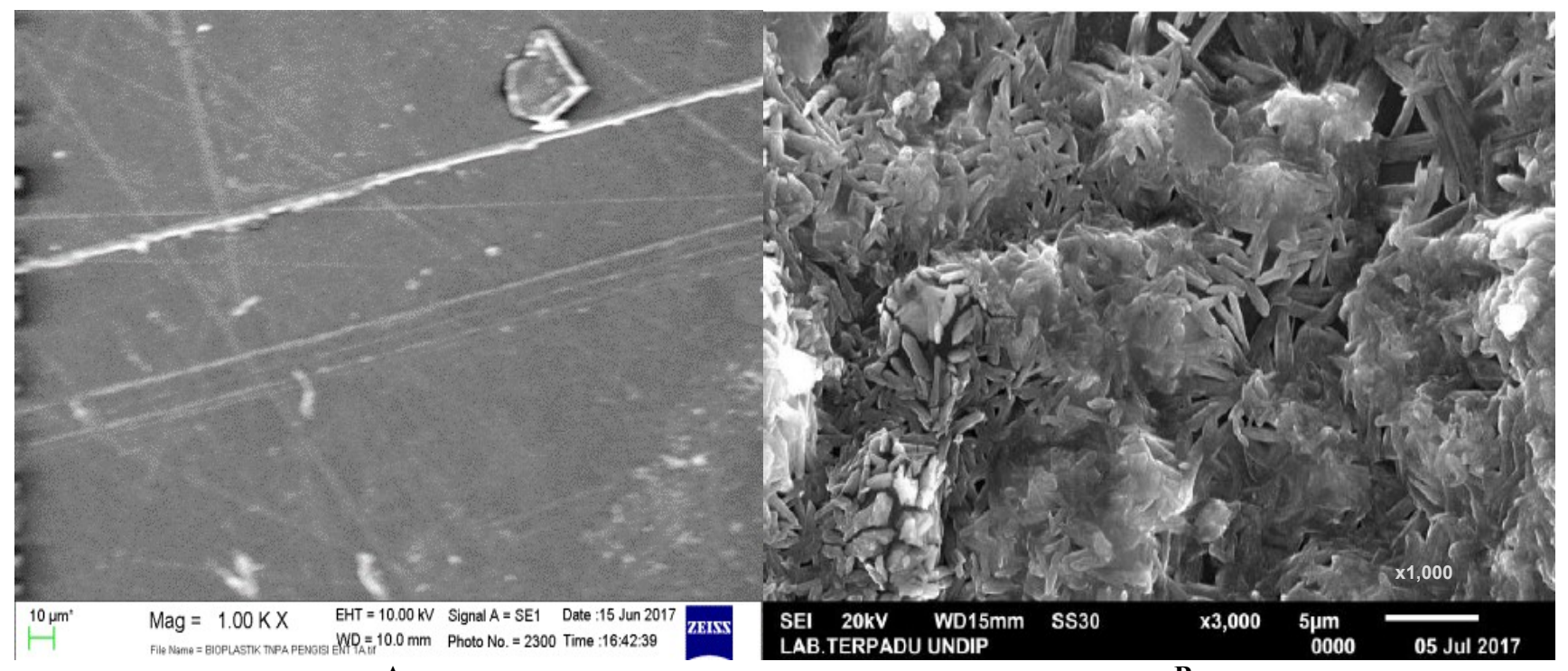

A

B

Figure 2. Scanning Electron Microscope of (A) Bioplastic filled without cacao pod husk, (B) Bioplastic filled with cacao pod husk

This result was also supported by morphological analysis scanning microscope (SEM) in Figures 2.A-B. The SEM analysis shows that bioplastic without the addition of cacao pod husk (Figure 2.A) showing the unwell-dispersed jackfruit seed starch relative to the time of mixing. It can be observed from quite a lot of white dots on the surface indicating the starch particles are not well-dispersed. On the other hand, a bioplastic the addition of cacao pod husk (Figure 2.B) shows that the surface of bioplastic was less refined structures; however, it had more compact and cohesive structure than that in non-filler bioplastic. Fewer surfaces might be caused by less homogeneous mixing materials (Ginting and Tarigan 2015). Interestingly, some empty hollow has also been found in this bioplastic. The presence of this empty cavity might be caused by air trapped in bioplastics during the drying process (BilbaoSainz et al. 2010).

\section{Elongation at break}

The elongation at break of bioplastic was shown in Figure 3. Result shows that the addition of ethylene glycol as plasticizers had increased the values of the tensile strength, with the optimum plasticizer addition was 0.4 $\mathrm{ml} /$ gram. The optimum value of bioplastic was $13.80 \%$. However, when the number of cacao pod husk increased, the value of elongation at break of bioplastic decreased. This might happen due to the higher cohesiveness of intermolecular bonds in bioplastics due to the increase of hydrogen bonds when the addition of fillers causing the bioplastic forms was stronger and stiffer. It could cause the decreased of intermolecular bonding distance (Ginting et al. 2015). In addition, the addition of fillers could reduce deformability, which occurred in the interphase region. Therefore, more and more interface region was formed, the elongation capability of bioplastic will be further reduced during breakup (Husseinsyah and Mostapha 2011). 


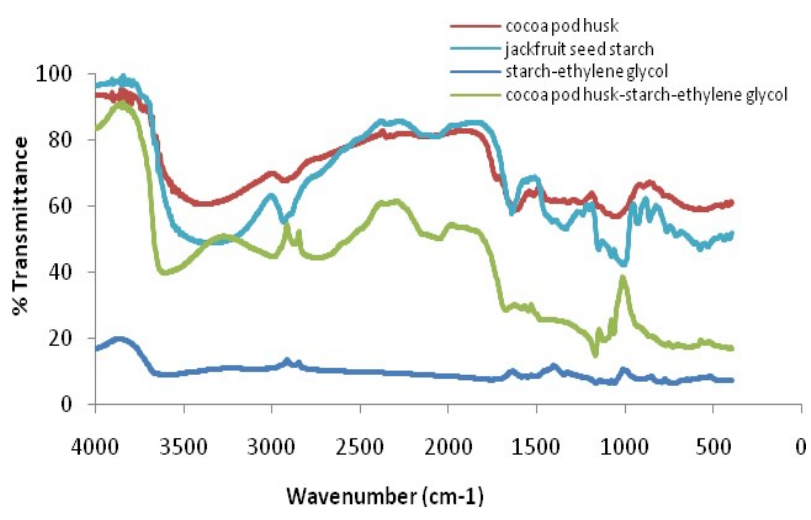

Figure 4. The effect of ethylene glycol addition on elongation at break of bioplastic

\section{Functional group analysis}

Figure 4 shows the functional group analysis of all used materials. The FT-IR analysis indicates that jackfruit seed consisted of many starch groups such as $\mathrm{O}-\mathrm{H}$ group, $\mathrm{C}-\mathrm{H}$ alkanes, $\mathrm{C}=\mathrm{C}$ alkanes, $\mathrm{C}=\mathrm{O}$ aldehyde and $\mathrm{C}-\mathrm{O}$ eter. The presence of those groups had represented the content of jackfruit seed starch which was consisted of amylose and amylopectin and glucose reduction $\left(\mathrm{C}_{6} \mathrm{H}_{10} \mathrm{O}_{5}\right)$ (Maulida et al. 2016). Besides, starch is containing fat and protein (Madruga et al. 2014). The existing of C-N amine and C-O ester indicates the presence of protein and fat which could be seen on wavelength of $1342.46 \mathrm{~cm}^{-1}$ and $1249,87 \mathrm{~cm}^{-1}$, respectively.

From FTIR analysis result, it shows that cacao pod husk contains the alcohol group existence such as, eter, carboxylic acid, and ester which was also reported by (Marbun 2012). While, cacao pod husk contains tannin, polyphenol, flavonoids, alkaloid and steroid which could be observed from the existence of $\mathrm{O}-\mathrm{H}$ group, $\mathrm{C}=\mathrm{O}$ group, $\mathrm{C}-\mathrm{O}$ group and $\mathrm{CH}_{3}$ group.

From figure 4, it could be seen the characteristics of bioplastic filled without cacao pod husk and bioplastic filled with cacao pod husk have the same functional groups. However, the behavior of spectrum on bioplastic filled without cacao pod husk used as filler lied under spectrum of bioplastic filled with cacao pod husk. It also has same functional groups with jackfruit seed starch as its constituent component.

In conclusions, from the SEM tests, the addition of cacao pod husk and ethylene glycol had less refined structures. However, it had more compact and cohesive structure than that in non-filler bioplastic. Bioplastic with the addition of cacao pod husk and ethylene glycol plasticizers could increase the values of the tensile strength of the optimum plasticizer addition $0.2 \mathrm{ml} / \mathrm{gram}$ was 15,40 Mpa. The addition of cacao pod husk decreased the elongation at break value was $13.80 \%$ on the optimum plasticizer addition was $0.4 \mathrm{ml} / \mathrm{gram}$. The FT-IR analysis indicates that jackfruit seed consisted of many starch groups such as $\mathrm{O}-\mathrm{H}$ group, $\mathrm{C}-\mathrm{H}$ alkanes, $\mathrm{C}=\mathrm{C}$ alkanes, $\mathrm{C}=\mathrm{O}$ aldehyde and $\mathrm{C}-\mathrm{O}$ eter

\section{ACKNOWLEDGEMENTS}

This work was supported partly by Research Laboratorium in the University of North Sumatera, Medan, Indonesia and other laboratories such as Integrated Laboratory, Diponegoro University, Semarang, Indonesia, and Physical Chemistry Laboratory, State University of Medan, Deli Serdang, Indonesia.

\section{REFERENCES}

Reddy RL, Reddy VS, Gupta GA. 2013. Study of bio-plastics as green \& sustainable alternative to plastic. Intl J Emerg Technol Adv Eng 3 (5): 2250-2459.

Gross RA, Karla B. 2002. Biodegradable polymers for the environment. Science 297: 803-807.

Azios T. 2007. A primer on biodegradable plastics. Christian Science Monitor. Retrieved from Academic One File database.

Skurtys O, Acevedo C, Pedreschi F, Enrione J, Osorio F, Aguilera JM. 2009. Food Hydrocolloid Edible Films and Coatings. Department of Food Science and Technology, Universidad de Santiago de Chile, Santiago.

Sahoo PK, Rana PK. 2006. Synthesis and biodegradability of starch-gethyl methacrylate/sodium acrylate/sodium silicate super absorbing composite. J Material Sci 41: 6470-6475.

Willet JL. 2009. Starch in polymer compositions. In: BeMiller JN, Whistler R (eds.) Starch: Chemistry and Technology. 3rd ed. Academic Press/Elsevier, Burlington London.

Zhao RX, Torley P, Halley PJ. 2008. Emerging biodegradable materials: starch-and protein-based bio-nanocomposites. J Material Sci 43 (9): 3058-3071.

Sanyang ML, Sapuan SM, Jawaid M, Ishak MR, Sahari J. 2015. Effect of plasticizer type and concentration on tensile, thermal and barrier properties of biodegradable films based on sugar palm (Arenga pinnata) starch. Polymers 7 (6): 1106-1124.

Iriany ES, Sunarti TC, Richana N, Mangunwidjaja D, Hadiyoso A. 2012. Utilization of corn hominy as a new source material for thermoplastic starch production. Procedia Chem 4: 245-253.

Tajan M, Chaiwutthinan P, Leejrkpai T. 2008. Thermal and mechanical properties of wood-plastics composites from iron wood flour and recycled polyurethane foam. J Metals Materials Minerals 18 (2): 5356.

Moghaddam AB, Nazari T, Badraghi J, Kazemzad M. 2009. Synthesis of $\mathrm{ZnO}$ nanoparicles and electrodeposition of polypyrrole/ZnO nanocomposite film. Intl J Electrochem Sci 4: 247-257.

Septiosari A, Latifah, Kusumastuti E. 2014. Pembuatan dan karakterisasi bioplastik limbah biji mangga dengan penambahan selulosa dan gliserol. Indonesian J Chem Sci 3 (2): 157-162.

Chun KS, Husseinsyah S, Osman H. 2014. Development of biocomposites from cocoa pod husk and polypropylene: effect of filler content and 3-aminopropyltriethoxylsilane. Polymers Renew Resour 5 (4): 139156.

Wijaya M, Wiharto M, Anwar M. 2017. Cellulose compound of cacao waste and chemical composition of cacao vinegar with GC-MS method. Jurnal Kimia dan Pendidikan Kimia 2 (3): 191-197. [Indonesian]

Marbun ES. 2012. Sintesis Bioplastik dari Pati Ubi Jalar Menggunakan Penguat Logam $\mathrm{ZnO}$ dan Penguat Alami Selulosa. [Skripsi]. Universitas Indonesia, Depok. [Indonesian]

Tong JY, Rajendran NR, Ng YC, Ab Ghani MH, Ahmad S. 2014. Study of the mechanical and morphology properties of recycled HDPE composite using rice husk filler. Adv Mater Sci Eng 2014, Article ID 938961, DOI: 10.1155/2014/938961.

Yusmarlela. 2009. Studi Pemanfaatan Plasticizer Gliserol dalam Film Pati Ubi dengan Pengisi Serbuk Batang Ubi Kayu. [Tesis]. Universitas Sumatera Utara, Medan. [Indonesian]

Maulida, Siagian M, Tarigan P. 2016. Production of starch-based bioplastic from cassava peel reinforced with microcrystalline cellulose Avicel PH101 using sorbitol as plasticizer. J Phys Conf Ser 710 012012. DOI: :10.1088/1742-6596/710/1/012012 
Sanyang ML, Sapuan SM, Jawaid M, Ishak MR, Sahari J. 2015. Effect of plasticizer type and concentration on tensile, thermal and barrie properties of biodegradable film based on sugar palm $(A$. pinnata $)$ starch. Polymers 7 (6): 1106-1124.

Rahmatunnisa R. 2015. Pengaruh Penambahan Nanopartikel ZnO dan Etilen Glikol Pada Sifat Fungsional Kemasan Biodegradable Foam dari Tapioka dan Ampok Jagung. Institut Pertanian Bogor, Bogor. [Indonesian]

Ginting MHS, Tarigan MFR. 2015. Effect of gelatinization temperature and chitosan on mechanical properties of bioplastic from avocado seed starch ( $P$. americana Mill) with plasticizer glycerol. Intl J Eng Sci 4 (12): 36-43.
Bilbao-Sáinz, Avena-Bustillos RJ, Wood DF, Williams TG, McHugh TH 2010. Composite edible films based on hydroxypropyl methylcellulose reinforced with microcrystalline cellulose nanoparticles. J Agric Food Chem 58: 3753-3760.

Ginting MHS, Tarigan MFR, Singgih AM. 2015. Effect of gelatinization temperature and chitosan on mechanical properties of bioplastics from avocado seed starch (Persea americana Mill) with plasticizer glycerol. Intl J Eng Sci 4 (12): 36-43.

Husseinsyah S, Mostapha M. 2011. The effect of filler content on properties of coconut shell filled polyester composites. Malaysian Polymer J 6: 87-97. 